\title{
PENGARUH GAYA KEPEMIMPINAN KEPALA SEKOLAH DAN KECERDASAN EMOSIONAL GURU TERHADAP KINERJA GURU SMK NEGERI DI KOTA METRO LAMPUNG
}

\author{
Farid Pathurrahman \\ SMKN 2 Metro Lampung \\ Email: faridpathurrahman@gmail.com
}

\author{
Juhri AM \\ Universitas Muhammadiyah Metro Lampung \\ Email: juhriam@gmial.com \\ Muhammad Ihsan Dacholfany \\ Universitas Muhammadiyah Metro Lampung \\ Email: muhammadihsan@gmail.com
}

\begin{abstract}
School Principal as the leader in particular school is influential to the teacher performance, in the effort of raising the performance in order to achieve the educational goal of the school. The leader has responsibility both physically and non-physically for the successful performance of the school. The principal's leadership must be able to influence all the school employees so that they are willing to work hard to improve performance voluntarily and passionately in achieving the vision, mission and goals of the school. Emotional Intelligence of the teacher will be able to send out warmth, awareness of one's own feelings, having sensitivity to the feelings of others and will be able to overcome emotional problems openly. This present study aims to: (1). know the contribution of principal's leadership style toward the state vocational teachers' performances in Metro City, Lampung, (2) know the contribution of the emotional intelligence of teachers to the performance of vocational state school teachers in Metro City, Lampung and (3) both the contribution of principal's leadership style and emotional intelligence of the teachers toward the state vocational teachers' in Metro City, Lampung.This research was descriptive study design used quantitative approach through regression analysis. This research aimed to know the influence between independent variable and dependent variable. The correlative study aimed to know whether there is any influence or not between two variables or more. The researcher decided 336 teachers as the population of the research and 77 teachers of 336 teachers as the sample of the research. The try out was 30 teachers of the rest of the research population which the sample has been previously determined. Due to theoretical assumption and the conclusions of data analysis, it can be concluded that: both the principal's leadership style (X1) and emotional intelligence $\left(X_{2}\right)$ have positive and significant contribution to the performance of teacher $(Y)$ of State Vocational Schools in Metro City. This conclusion was supported by the analysis findings. There was positive and significant contribution of the principal's leadership style toward the teacher's performance. The number of the contribution of the principal's leadership style to performance in this study was based on the results of calculations at the sufficient category. There was positive and significant contribution between emotional intelligence on teacher performance. The number of emotional intelligence contribution to teacher performance in this study was based on the results of calculations at the sufficient category and simultaneously there was
\end{abstract}


a positive and significant contribution between the principal's leadership style and emotional intelligence on teacher performance. The dimension of leadership style influenced the teacher's performance were administrator, class manager, mediator, facilitator and evaluator. The contribution number of principal leadership style and the emotional intelligence toward the performance of the teacher.

Keywords: Influence, Leadership Style, Emotional Intelligence, Against Performance.

\begin{abstract}
Abstrak
Kepala Sekolah sebagai pimpinan pada sekolah tertentu sangat berpengaruh terhadap kinerja guru, dalam upaya meningkatkan kinerja guna mencapai tujuan pendidikan sekolah. Pemimpin memiliki tanggung jawab baik secara fisik maupun non fisik untuk keberhasilan kinerja sekolah. Kepemimpinan kepala sekolah harus dapat mempengaruhi seluruh pegawai sekolah agar mau bekerja keras untuk meningkatkan kinerja secara sukarela dan penuh semangat dalam mencapai visi, misi dan tujuan sekolah. Kecerdasan Emosional guru akan mampu memancarkan kehangatan, kesadaran akan perasaan sendiri, memiliki kepekaan terhadap perasaan orang lain dan akan mampu mengatasi masalah emosi secara terbuka.Penelitian ini bertujuan untuk: (1). mengetahui kontribusi gaya kepemimpinan kepala sekolah terhadap kinerja guru SMK negeri di Kota Metro Lampung, (2) mengetahui kontribusi kecerdasan emosional guru terhadap kinerja guru SMK Negeri di Kota Metro, Lampung dan (3) keduanya Kontribusi Gaya Kepemimpinan Kepala Sekolah dan Kecerdasan Emosional Guru terhadap Guru SMK Negeri di Kota Metro Lampung.Penelitian ini merupakan penelitian deskriptif dengan pendekatan kuantitatif melalui analisis regresi. Penelitian ini bertujuan untuk mengetahui pengaruh antara variabel bebas dan variabel terikat. Studi korelatif bertujuan untuk mengetahui ada tidaknya pengaruh antara dua variabel atau lebih. Peneliti menetapkan 336 guru sebagai populasi penelitian dan 77 guru dari 336 guru sebagai sampel penelitian. Uji coba dilakukan pada 30 guru dari sisa populasi penelitian yang telah ditentukan sampelnya sebelumnya.Berdasarkan asumsi teoritis dan kesimpulan analisis data, dapat disimpulkan bahwa: baik gaya kepemimpinan kepala sekolah (X1) maupun kecerdasan emosional (X2) memiliki kontribusi positif dan signifikan terhadap kinerja guru (Y) SMK Negeri di Metro. Kota. Kesimpulan ini didukung oleh temuan analisis. Ada kontribusi positif dan signifikan gaya kepemimpinan kepala sekolah terhadap kinerja guru. Besarnya kontribusi gaya kepemimpinan kepala sekolah terhadap kinerja dalam penelitian ini didasarkan pada hasil perhitungan pada kategori cukup. Ada kontribusi positif dan signifikan antara kecerdasan emosional terhadap kinerja guru. Besarnya kontribusi kecerdasan emosional terhadap kinerja guru dalam penelitian ini berdasarkan hasil perhitungan pada kategori cukup dan secara simultan terdapat kontribusi yang positif dan signifikan antara gaya kepemimpinan kepala sekolah dan kecerdasan emosional terhadap kinerja guru. Dimensi gaya kepemimpinan yang mempengaruhi kinerja guru adalah administrator, manajer kelas, mediator, fasilitator dan evaluator. Kontribusi jumlah gaya kepemimpinan kepala sekolah dan kecerdasan emosional terhadap kinerja guru.
\end{abstract}

Kata Kunci: Pengaruh, Gaya Kepemimpinan, Kecerdasan Emosional, Terhadap Kinerja.

\title{
A. Pendahuluan
}

Gaya kepemimpinan merupakan hal yang sangat penting dalam kehidupan berorganisasi. Dengan gaya kepemimpinan, kinerja sebuah organisasi dapat berjalan secara maksimal. Demikian juga dengan sekolah sebagai lembaga pendidikan. Dengan gaya kepemimpinan yang baik, maka sebuah institusi 
pendidikan akan dapat berkembang secara optimal sebagaimana diharapkan. Manajemen pendidikan di Indonesia merupakan titik sentral dalam mewujudkan tujuan pembangunan SDM.

Kinerja guru tidak terlepas dari peran seorang kepala sekolah sebagai pimpinan yang mempunyai wewenang untuk memerintah orang lain, kepala sekolah berperan aktif menyelesaikan persoalan-persoalan yang timbul dari bawahannya dan itu sekaligus tantangan yang harus dihadapi oleh seorang pimpinan karena itu kepala sekolah senantiasa menghadapi dan mengerahkan semua kekuatannya untuk memecahkan persoalan pada bawahannya, akan tetapi upaya yang dilakukan seorang kepala sekolah tidak semudah yang kita pikirkan kepala sekolah terkendala oleh banyak hal seperti sikap bawahan/guru dalam menafsirkan perintah yang diberikan oleh pimpinan dalam hal ini kepala sekolah, sering kita menemukan adakalanya terjadi kontradiksi kemauan antara pimpinan dan bawahan, antara guru dan kepala sekolah, apa yang diinginkan kepala sekolah tidak dapat ditangkap atau diterima oleh guru sehingga menimbulkan prasangka. Pimpinan yang baik dalam menjalankan kepemimpinannya merupakan point di mana organisasi ingin meningkatkan dan mengembangkan knowledge dan ability individu. Sesuai dengan kebutuhan masa kini maupun masa datang. Menyadari berbagai hal tersebut pencapaian Tujuan Pendidikan Nasional pada umumnya dan khususnya pencapaian tujuan pendidikan di wilayah Lampung Timur. Tanpa seorang pemimpin sesuatu organisasi tak lain merupakan campur aduk manusia dan peralatan dalam suatu tempat, kepemimpinan merupakan kecakapan untuk mengendalikan, mengatur orang-orang agar berperan sesuai fungsinya masing-masing, kepemimpinan dapat menjadi penyemangat, menjadi motivasi bagi para bawahan bekerja.

Kepemimpinan adalah proses mempengaruhi atau memberi contoh oleh pimpinan kepada bawahannya dalam upaya mencapai tujuan organisasi. Kepemimpinan sesungguhnya tidak ditentukan oleh pangkat ataupun jabatan seseorang. Kepemimpinan adalah sesuatu yang muncul dari dalam dan merupakan buah dari keputusan seseorang untuk mau menjadi pemimpin, baik bagi dirinya sendiri, bagi keluarganya, bagi lingkungan pekerjaannya, maupun bagi lingkungan sosial dan bahkan bagi negerinya. Dalam teori asal mula lahirnya negara secara primer ditemui istilah "Primus Interparens" artinya yang utama diantara sesama, dimana seorang pemimpin itu muncul karena kelebihan yang dimiliki oleh seseorang, seperti kelebihan seseorang secara fisik (badannya) yang besar, tenaganya yang kuat, umurnya yang paling tua.

Dengan kelebihan yang dimiliki oleh seseorang itu maka ia disegani oleh sesamanya anggota kelompoknya dia menjadi yang utama dan dipercaya untuk menyelesaikan segala persoalan yang terjadi, baik menyelesaikan konflik maupun memimpin sebuah pekerjaan, tetapi seiring perkembangan zaman pemimpin tidak lagi ditentukan semata hanya karena keunggulan fisik semata tapi juga keunggulan wawasan, kecerdasan, kompetensi bawahan, kepatuhan atau 
ketaatan bawahan dalam menjalankan perintah pimpinan, tiap orang memiliki kecerdasan yang berbeda seperti kecerdasan sosial, kecerdasan managerial, kecerdasan ekonomi, kecerdasan teknologi, apabila seseorang menguasai satu kecerdasan ia akan unggul dan menjadi modal untuk menjadi pemimpin.

Pada jaman modern seperti saat ini, kepemimpinan tidak terfokus pada satu keturunan, siapa saja yang memiliki kecerdasan maka dia berpeluang menjadi pemimpin. Kepemimpinan seseorang tidak semata hanya ditentukan oleh kelebihannya secara fisik seperti badan yang besar tetapi lebih ditentukan cara atau gaya orang itu memimpin atau mempengaruhi bawahannya. Berhasil atau tidaknya seseorang memimpin dengan gaya yang dimilikinya tentu juga tidak terlepas dari faktor lain seperti tingkat pendidikan, minat motivasi, semangat, kedisiplinan, tingkat usia, jenis kelamin, tingkat kecerdasan, tingkat emosi, sarana yang tersedia, situasi/kondisi, tingkat ekonomi, lingkungan dan sebagainya.

Dari sekian banyak faktor yang mendukung keberhasilan seorang pemimpin penulis dalam makalah ini akan mengangkat permasalahan dimana kepemimpinan dipengaruhi oleh kecerdasan emosi. Adakalanya seorang pemimpinmemberikan perintah berdasarkan hal-hal yang sifatnya subjektif atau lebih ditonjolkan yang pribadi. Bawahan atau orang yang dipimpin juga sering tidak dapat menerima kebijakan yang dibuat pimpinan.

Adapun faktor yang sifatnya pribadi, cenderung berprasangka buruk terhadap kebijakan yang dibuat. Antara pemimpin dan yang dipimpin sering terjadi saling menyalahkan, bawahan sering menganggap dirinya sebagai kuli dan harus patuh dengan segala perintah atasan. Akibatnya, banyak bawahan yang memendam idenya. Sebaliknya, atasan kerap menganggap dirinya lebih unggul dan berpengalaman di banding bawahannya. Idealnya, seorang atasan juga harus memahami keinginan dan cita-cita bawahannya. Pemahaman seperti ini akan membuat bawahan betah bekerja di bawah kepemimpinan atasan. Keberhasilan pemimpin terlihat jika bawahan rela dipimpin dalam bekerja. "Pemimpin mampu membuat bawahan bahagia di saat bekerja."

Selain faktor gaya kepemimpinankepala sekolah dalam memipin lembaganya, terdapat faktor lain yang dapat mempengaruhi kinerja guru, yaitu kecerdasan emosi (EI) kerja guru. Kinerja guru dapat dipengaruhi oleh kecerdasan emosi kerja yang dimiliki para guru itu sendiri, sehingga ada pengaruh timbal balik antara kecerdasan emosi dan kinerja guru. Kecerdasan emosi merupakan istilah yang belum lama dikenal baik di dunia psikologi dan sosial pada umumnya. Sebagai sandingan IQ (Intelligence Quotient), aspek terpenting EI berada pada mental dan emosi. Topik tentang EI menjadi ramai dibicarakan oleh masyarakat luas setelah terbitnya buku karya Daniel Goleman pada tahun 1995 yang berjudul EI (EmotionalIntelligence).

Emotional Intelligence yang dimiliki seorang guru akan mampu memancarkan kehangatan, kesadaran akan perasaan sendiri, memiliki sensivitas 
terhadap perasaan orang lain serta akan mampu mengatasi masalah emosi secara terbuka. Guru merupakan salah satu sumber daya manusia yang berada pada lembaga pendidikan, Kecerdasan emosional guru sangatlah diperlukan untuk dapat melaksanakan tugasnya. Kecerdasan itu sendiri meliputi kemampuan membaca, menulis, berhitung, yang akan mampu mengarahkan seseorang untuk mencapai sukses di bidang akademis, meskipun saat ini diketahui bahwa keberhasilan hidup tidak terbatas pada faktor pendidikan saja.

Berdasarkan masalah yang dibahas pada uraian sebelumnya maka dapat dirumuskan masalah penelitian sebagai berikut:

1. Apakah ada kontribusi dari gaya kepemimpinan kepala sekolah terhadap kinerja guru SMK Negeri di Kota Metro Lampung?

2. Apakah ada kontribusi dari kecerdasan emosional guru terhadap kinerja guru SMK Negeri di Kota Metro Lampung?

3. Apakah ada kontribusi dari gabungan gaya kepemimpinan kepala sekolah dan kecerdasan emosional guru secara bersama-sama terhadap kinerja guru SMK Negeri di Kota Metro Lampung?

\section{B. Pembahasan}

\section{Kinerja}

Kinerja sering dikatakan kinetika hal ini sejalan dengan pendapat Wirawan menyebutkan "kinerja sering juga disebut dengan kinetika kerja atau performance", kinerja juga merupakan suatu fungsi dari hasil atau apa yang dicapai seorang karyawan dan kompetisi yang dapat menjelaskan bagaimana karyawan dapat mencapai hasil tersebut. Kinerja adalah prestasi yang dicapai karyawan dalam melaksanakan suatu pekerjaan dalam suatu organisasi, agar dapat memberikan umpan balik bagi karyawan maupun organisasi, maka perlu dilakukan penilaian atas prestasi tersebut. Adapun menurut Dacholfany \& Astuti mengemukakan bahwa kinerja guru adalah kemampuan dan kewenangan guru dalam menjalankan profesi keguruan dengan beberapa cakupan indikator yaitu sebagai berikut; 1) membuat perencanaan pembelajaran, 2) melaksanakan pembelajaran, 3) melaksanakan evaluasi pembelajaran, dan 4) melaksanakan tindak lanjut hasil evaluasi belajar.

Sejalan dengan pendapat tersebut menurut Wirawan yang dimaksud dengan kinerja guru adalah "hasil yang dicapai seorang guru dalam mengelola proses belajar mengajar dan usaha-usaha yang dilakukannya dalam menjalankan tugas dan kewajbannya". Keberhasilan yang dapat dicapai dari hasil pembelajaran seorang pendidik dapat dilakukan dengan berbagai cara menyampaikan materi pembelajaran, sehingga peserta didik mudah dalam memahaminya. Pentingnya kinerja guru juga dikemukakan Sanjaya mengajar bukanlah hanya menyampaikan materi pelajaran saja, akan tetapi merupakan pekerjaan yang bertujuan yang bersifat komplek. Hendaknya dalam pelaksanaannya diperlukan sejumlah 
keterampilan khusus yang didasarkan pada konsep dan ilmu pengetahuan yang spesifik.

Berdasarkan dari uraian diatas maka peneliti berkesimpulan bahwa kinerja adalah prestasi yang dicapai karyawan dalam melaksanakan suatu pekerjaan dalam suatu organisasi, agar dapat memberikan umpan balik bagi karyawan maupun organisasi. Begitu pula seorang guru keberhasilan yang dicapai manakala peserta didik menjadi paham dan memahami terhadap materi pembelajaran.

\section{Gaya}

Para ahli dibidang kepemimpinan telah meneliti dan mengembangkan gaya kepemimpinan yang berbeda-beda sesuai dengan evaluasi teori kepemimpinan. Gaya kepemimpinan merupakan dasar dalam mengklarifikasikan tipe kepemimpinan. Gaya kepemimpinan mempunyai tiga pola dasar yaitu mementingkan tugas, mementingkan hubungan kerjasama dan mementingkan hasil yang dicapai seperti yang dikemukakan oleh Rivai bahwa gaya kepemimpinan adalah sekumpulan ciri yang digunakan pimpinan untuk mempengaruhi bawahan agar sasaran organisasi tercapai atau dapat pula dikatakan bahwa gaya kepemimpinan adalah pola perilaku dan strategi yang disukai dan sering diterapkan oleh seorang pemimpin.

Dalam hal ini kepala sekolah dalam hal ini Kehadiran kepala sekolah sebagai seorang pemimpin ini merupakan sebuah alat penggerak dan penentu arah kebijakan sekolah (Sinta Oktaviantil dan M. Ihsan Dacholfany. Gaya kepemimpinan menggambarkan kombinasi yang konsisten dari falsafah, keterampilan, sifat, dan sikap yang menandai perilaku seseorang. Gaya kepemimpinan yang menunjukan secara langsung maupun tidak langsung tentang keyakinan seorang pemimpin terhadap kemampuan bawahannya. Artinya gaya kepemimpinan adalah perilaku dan sifat, sikap-sikap yang sering diterapkan oleh seorang pemimpin ketika ia mencoba mempengaruhi kinerja bawahannya.

Untuk menentukan gaya yang paling efektif dalam menghadapi keadaan tertentu maka menurut Dacholfany konsep kepemimpinan mencakup sekurangkurangnya tiga unsur yaitu seorang pemimpin yang memimpin, mempengaruhi dan memberikan bimbingan; anggota atau bawahan yang dikendalikan dan tujuan yang diperjuangkan melalui serangkaian kegiatan.

Dengan demikian, kepemimpinan kepala sekolah adalah pengaruh kepada orang lain melalui interaksi individu dan kelompok sebagai wujud kerjasama dalam organisasi untuk mencapai tujuan yang telah ditetapkan secara efektif dan efisien. Dari penjelasan di atas, maka dapat disimpulkan bahwa kepemimpinan kepala sekolah dalam kepemimpinannya kepala sekolah memiliki gaya dalam memimpin. Gaya inilah yang dapat dipersepsikan oleh semua bawahan. 


\section{Kecerdasan Emosional}

Beberapa ahli membedakan pengertian kecerdasan emosi sebagai berikut:

a. Menurut Daniel Goleman kecerdasan emosi adalah kemampuan seperti kemampuan untuk memotivasi diri sendiri dan bertahan menghadapi frustasi, mengendalikan dorongan hati dan tidak melebih-lebihkan kesenangan, mengatur suasana hati dan menjaga agar beban stress tidak melumpuhkan kemampuan berpikir, berempati dan berdo'a.

b. Menurut Agus Efendi kecerdasan emosi adalah jenis kecerdasan yang fokusnya memahami, mengenali, merasakan, mengelola, dan memimpin perasaan diri sendiri dan orang lain serta mengaplikasikannya dalam kehidupan pribadi dan sosial.Pendapat lain, menurut Uno kecerdasan emosi adalah kemampuan mengenali perasaan kita diri sendiri dan perasaan orang lain kemampuan mengelola emosi dengan baik pada diri sendiri, dan dalam hubungannya dengan orang lain Thomas R. Hoerr, Buku Kerja Multiple Intelligence, Daniel Goleman, Emotional Intelligence, mengapa EI lebih penting daripada IQ, Agus Effendi, Revolusi Kecerdasan Abad 21, Hamzah B Uno, Orientasi Baru dalam Psikologi Pembelajar Menurut Howard Gardner kecerdasan emosi terdiri dari dua kecakapan yaitu Intrapersonal Intelligence (kemampuan untuk memahami diri sendiri dan bertanggung jawab atas kehidupannya sendiri) dan Interpersonal Intelligence (kemampuan untuk berhubungan dengan orang lain dan sekitarnya).

\section{Kontribusi Gaya Kepemimpinan Kepala Sekolah terhadap Kinerja Guru pada SMK Negeri di Kota Metro Lampung.}

Dari hasil pengujian signifikansi diperoleh skor probabilitas (sig) sebesar 0,000, dengan demIkian koefisien regresi adalah signifikan atau model regresi dapat digunakan untuk memprediksi Kinerja Guru yang menggambarkan kebermaknaan pengaruh antara gaya kepemimpinan kepala solah terhadap kinerja guru sangat signifikan sehingga dapat dijelaskan bahwa:

a. Kinerja guru tanpa didukung gaya kepemimpinan kepala sekolah (konstant) besarnya adalah 71,719.

b. Setiap perubahan atau peningkatan variabel gaya kepemimpinan kepala sekolah akan menaikan dan atau menentukan tingkat kinerja guru setiap ada kenaikan 1 point pada variabel gaya kepemimpinan kepala sekolah akan berakibat naiknya skor variabel kinerja guru sebesar 0,422. Dengan demikian hioptesis Kinerja Guru SMK Negeri di Kota Metro Lampung sebesar $8,3 \%$.

c. Hasil penelitian ini mengindikasikan bahwa semakin baik tingkat kepemimpinan kepala sekolah akan diikuti oleh peningkatnya kinerja guru. Hal ini sejalan dengan pendapat Mulyasa (2013:89) kepala sekolah professional dalam paradigma baru manajemen, pendidiikan akan 
memberikan dampak positif dan perubahan yang mendasar dalam pembaharuan sistem pendidikan di sekolah. Dampak lainnya terhadap efektifitas pendidikan, kepemimpinan kepala sekolah yang kuat, pengelolaan tenaga pendidikan yang efektif, budaya mutu, tim work yang kompak, cerdas, mandiri, partisipasi warga sekolah dan masyarakat, keterbukaan manajemen, kemauan untuk berubah, evaluasi dan perbaikan yang berkelanjutan, responshif dan antisipasi.

Hal itu secara langsung berkaitan dengan perarutran pemerintah no. 28 tahun 1990 yang menyatakan bahwa "kepala sekolah bertanggung jawab atas penyelenggaraan pendidikan, administrasi sekolah, pembinaan tenaga kependidikan lainnya dan pendayagunaan serta pemeliharaan sarana dan prasarana".

Jelas sekali bahwa gaya kepemimpinan kepala sekolah sangat mempengaruhi terhadap hasil kerja guru yang dipimpinnya, jika kepala sekolah mampu memahami dan mengkondisikan sekolah sesuai dengan kebutuhan dan kemampuan yang dicapai sekolah maka akan meningkat kinerja guru dalam menyampaikan materi pembelajaran kepada peserta didik. Begitu juga sebaliknya, jika gaya kepemiminan tidak baik dan belum merespons terhadap kemampuan sekolah yang dipimpinnya, maka dapat mempengaruhi terhadap kinerja guru yang tidak baik.

\section{Kontribusi Kecerdasan Emosional terhadap Kinerja Guru di SMK Negeri Kota Metro, Lampung}

Terdapat kontribusi positif dan signifikan anatara kecerdasan emosional terhadap kinerja guru pada sekolah SMK Negeri di SMK Kota Metro, Lampung (Y). Hal ini dapat diterangkan oleh persamaan regresi $\breve{Y}=38,438+0.344 \mathrm{X}_{2}$. Dengan persamaan regresi tersebut dapat diinterpretasikan bahwa jika kecerdasan emosional $\left(\mathrm{X}_{2}\right)$ dengan kinerja guru $(\mathrm{Y})$ diukur dengan instrumen yang dikembangkan dalam penelitian, maka setiap perubahan skor variabel kecerdasan emosional sebesar 38,438 satu satuan dapat diestimasikan skor kinerja guru akan berubah sebesar 0,344 satuan pada arah yang sama. Dari perhitungan antara variabel kecerdasan emosional $\left(\mathrm{X}_{2}\right)$ terhadap Kinerja Guru $(\mathrm{Y})$ tergolong rendah, yaitu sebesar 0,344, ini menunjukan antara variabel $\mathrm{X}_{2}$ dan variabel $\mathrm{Y}$ memiliki kontribusi yang berarti. Secara empiris, hasil penelitian menginformasikan bahwa kecerdasan emosional yang dicerminkan dalam proses kerja berkontribusi secara signifikan dan positif terhadap kinerja guru.

Besarnya kontribusi kecerdasan emosional terhadap kinerja guru SMK Negeri di Kota Metro adalah sebesar 8,85\% hasil dari penelitian ini mengindikasikan bahwa semakin besar kecerdasan emosional akan diikuti oleh semakin tingginya kinerja guru. Hal ini sejalan dengan pendapat yang dikemukakan oleh Daniel Goleman yang berjudul Emotional Intelligene.Istilah kecerdasan emosional pertama kali dilontarkan pada tahun 1990 oleh psikolog 
Peter Solofey dari Yale University dan John Mayer dari university of New Ham See HAAAa.

Mereka menggambarkan kecerdasan emosional sebagai "a form of social intelligence thats involpafe the abiliyti to want own and other s feelings and emotion, tought discreas among them and to us this information thought with want ..." maksudnya adalah himpunan bagian dari kecerdasan sosiaol yang melibatkan kemampuan memantau perasaan dan emosi baik pada diri sendiri maupun pada orang lain, memilah-milah semuanya dan menggunakan informasi ini untuk membimbing pikiran dan tindakan.

Definisi yang tidak jauh berbeda dengan definisi diatas, dikemukan pula oleh Daniel bahwa kecerdasan emosional adalah kemampuan mengenali perasaan kita sendiri dan perasaan orang lain,kemampuan memotivasi diri sendiri dan kemampuan mengelola emosi dengan baik pada diri sendiri dan dalam hubungan dengan orang lain,

\section{Kontribusi Gaya Kepemimpinna Kepala Sekolah dan Kecerdasan Emosional Secara Bersama-sama Terhadap Kinerja Guru SMK Negeri di Kota Metro Lampung.}

Terdapat kontribusi positif dan signifikan antara gaya kepemimpinan kepala sekolah $\left(X_{1}\right)$ dan kecerdasan emosional $\left(X_{2}\right)$ serara bersama-sama terhadap kinerja guru (Y). Hasil penelitian menunjukan bahwa semakin baik gaya kepemimpinan kepala sekolah dan kinerja guru semakin baik pula kontribusinya terhadap kinerja guru. Hal ini dapat diterangkan oleh persamaan regresi $\breve{Y}=$ $56,715+0,398 X_{1}+0,325 X_{2}$.

Dengan persamaan regresi tersebut diinterpretasikan bahwa variabel gaya kepemimpinan kepala sekolah $\left(X_{1}\right)$ dan variabel kecerdasan emosional $\left(X_{2}\right)$ dengan kinerja guru (Y) diukur dengan instrumen yang dikembangkan dalam penelitianini, maka setiap perubahan skor gaya kepemimpinan kepala sekolah dan kecerdasan emosional sebesar 1 satuan $X_{1}$ dan 0,398 satuan $X_{2}$ pada arah yang sama. Dariperhitungan regresi antar kepemimpinan kepala sekolah $\left(X_{1}\right)$ dan kecerdasan emosional $\left(\mathrm{X}_{2}\right)$ terhadap kinerja guru $(\mathrm{Y})$ tergolong sedang, yaitu 0,433. Hal ini menunjukan antara variabel $X_{1}$ dan variabel $X_{2}$ dengan variabel $Y$ dengan pengaruh yang berarti meskipun regresinya tergolong sedang. Besarnya kontribusi gaya kepemimpinan kepala sekolah dan kinerja guru secara bersamasama terhadap kinerja guru pada SMK Negeri di kota Metro adalah 16,2 \%.

Hasil penelitian ini mengindikasikan bahwa semakin semakin baik gaya kepemimpinan kepala sekolah akan diikuti oleh meningkatnya perubahan kinerja guru, hasil penelitian ini mengindikasikan bahwa semakin besar kecerdasan emosional, akan diikuti oleh semakin tingginya kinerja guru. Secara empiris, hasil penelitian ini menginformasikan bahwa gaya kepemimpinan dan kecerdasan emosional secara bersama-sama memberikan kontribusi positif dan signifikan terhadap kinerja guru. 
Berdasarkan temuan empiris yang menunjukan adanya kontribusi yang positif dan signifikan antar variabel kepemimpinan kepala sekolah dan variabel kecerdasan emosional secara bersama terhadap kinerja guru, hal ini senada dengan pendapat Mulyasa menyimpulkna bahwa peran pemimpin berpengaruh terhadap kinera pegawai demi meningkatkan tujuan.Pemimpin mempunyai tanggung jawab, baik secara fisik maupun secara spiritual terhadap keberhasiln kinerja yang dipimpinnya. Koontz dalam kamars mengatakan bahwa kepemimpinan (Leadership) adalah sebagai pengaruh, seni atau proses mempengaruhi orang-orang sehingga mereka mau bekerja keras dalam meningkatkan kinerja sukarela dan bersemangat ke arah tujun kelompok. Robin (1984) mengdefinisikan kepemimpinan sebagai berikut: Leadership is the ability to influence a group towards the achievement of goals, the source of this influence may be formal, shoud as taht provide by the position of managerail rank in and organizationan.

Selain faktor kepemimpinan gaya sekolah, faktor lainnya yang dapat mempengaruhi kinerja guru adalah kecerdasan emosional kerja guru. Hasil penelitian Kusumawati menyatakan bahwa kinerja pegawai dapat dipengaruhi oleh kecerdasan emosi yang di milikinya.Haal ini di dukung oleh pendapat colquitt, dkk menyatakana kecerdaasan emosi kerja secara umum merupakan hubungan positif antara kinerja. Gibson secara jelas menggambarkan adanya hubungan.Timbal balik antara kecerdasan emosi dan kinerja guru. Pengaruh gaya kepemimpinan kepala sekolah dan kecerdasan emosional terhadap kinerja guru di SMK Negeri di Kota Metro menunjukan dampak yang Positif.

\section{Simpulan}

Berdasarkan kajian teoritis dan simpulan hasil analisis data maka dapat disimpulkan bahwa : gaya kepemimpinan kepala sekolah dan kecerdasan emosiomal secara bersama-sama memberikan kontribusi yang positif dan signikan terhadap kinerja guru SMK Negeri di Kota Metro. Simpulan ini didukung dari temuan hasil analisis sebagai berikut. Pertama, terdapat kontribusi positif dan signifikan antara gaya kepemimpinan kepala sekolah terhadap kinerja guru. Besarnya kontribusi gaya kepemimpinan kepala sekolah terhadap kinerja dalam penelitian ini berdasarkan hasil perhitungan pada kategori cukup. Dimensi gaya kepemimpinan kepala sekolah yang memberikan kontribusi cukup signifikan adalah aspek kemampuan menjalankan satuan kerjanya untuk lebih baik. Gaya kepemimpinan kepala sekolah jika diukur pada aspek kinerja guru adalah bagaimana kepala sekolah melakukan hal-hal sebagai berikut: delegatif, konsultatif, partiipatif dan instruktif. Dalam penelitian ini gaya kepeminpinan kepala sekolah memiliki kontribusi yang signifikan terhadap tinggi rendahnya kualitas hasil kinerja guru. Pengaruh gaya kepemimpinan kepala sekolah terhadap kinerja guru pada SMK Negeri di Kota Metro sebesar 8,3\%, selebihnya dipengaruihi oleh faktor lain. Kedua, ada kontribusi positif dan signifikan antara kecerdasan emosional terhadap kinerja guru. Besarnya kontribusi kecerdasan 
emosional terhadap kinerja guru dalam penelitian ini berdasarkan hasil perhitungan pada kategori cukup. Dimensi kecerdasan emosional yang memberikan kontribusi secara signifikan adalah kesaadran diri, pengaturan diri, motivasi diri, empati dan membina hubungan dengan guru. Dengan demikian, jelaslah bahwa kecerdasan emosional berkontribusi secara positif dan signifikan terhadap kinerja guru sebesar $8.8 \%$, selebihnya dipengaruhi oleh faktor lain diluar penelitian ini. Ketiga, secara simultan ada kontribusi yang positif dan signifikan antara gaya kepemimpinan kepala sekolah dan kecerdasan emosional terhadap kinerja guru. Dimensi gaya kepemimpnan memberi pengaruh terhadap kinerja guru adalah administrator, peengelola kelas, mediatator, fasilitator, evaluator. Besarnya kontribusi gaya kepemimpinan kepala sekolah dan kecerdan emossional terhadaap kinerja guru sebesar $16,2 \%$, sisanya merupakan pengaruh dari faktor lainnya.

\section{Referensi:}

Agung, Iskandar, Mengembangkan professionalitas Guru, Jakarta: Media Pustaka, 2014.

Ali Muhidin Sambas, Analisis Korelasi Regresi dan Jalur, Bandung: Balai Pustaka Setia, 2004.

A.M. Sardiman, Interaksi dan Motivasi Belajar Mengajar, Jakarta: Rajawali Pers, 2004..

Juhri, AM, Kepemimpinan dan Supervisi Pengajaran, Bandar Lampung: Gunung Pesagi, 1997.

Juhri, AM, Landasan dan Wawasan Pendidikan.Metro, Lembaga Penelitian UM Metro Press, 2015.

Arikunto, Suharsimi, Prosedur Penelitian Suatu Pendekatan Praktik, Yogyakarta: Rineka Cipta, 1993.

Atmodiwiro, Soebagyo, Manajemen Pendidikan Indonesia, Jakarta: Ardadizya Jaya, 2003.

Badan Akreditadi Nasonal S/M Lampung, Laporan Akhir Pelaksanaan Akreditasi Sekolah Madrasah Provinsi lampung 2018.Lampung, BAN S/M Lampung Tahun 2018.

Bennis, Wetrren dan Townsend Robert,Reinvetting Leadership, Batam: Inter Angkasa, 1998..

Canter, Kihlstorm, Personality, Cognitio and Social Interactions, Hillsdale: NJ. Elrbaum, 1987.

Colquitt, dkk, Organizational Behavior, New York: Megraw Hill Companies, Inc, 2009.

Cooper, Sanjaya, Strategi Pembelajaran Berorientasi Standar Proses Pendidikan, Jakarta: Prenada, 2009.

Colin, dkk, Professional Development for Educational Management, Jakarta: Grasind, 2004. 
Dacholfany, Ihsan, Leadership Style in Character Educationat The Darussalam Gontor Islamic Boarding, Al-Ulum V-15, 2015.

Dacholfany dan R Astuti, Pengaruh Supervisi Pengawas Sekolah dan kepemimpinan Kepala Sekolah Terhadap Kinerja Guru SMPdi Kota Metro Lampung. Metro. Jurnal Lentera Pendidikan Pusat Penelitian LPPM UM Metro.

Dacholfany, M.Ihsan,Peran Kepemimpinan Perguruan Tinggi Islam Dalam Pembangunan Peradaban Islam STAIN Jura Siwo,Nizham Journal Of Islamic Studies, Vol. 01, No. 02, Tahun 2013.

Daviz \& Sutisna, Perilaku Konsumen dan Komunikasi Pemasaran, Bandung: T. Remaja Rosdakarya, 2002.

Dharma, Surya, Manajemen Kinerja, Jakarta: Pustaka Pelajar, 2005.

Departemen Pendidikan dan Kebudayaan,Petunjuk Peningkatan Mutu Pendidikan di Sekolah Dasar Jakarta: Direktorat Jenderal Pendidikan Dasar dan Menengah, 1994.

Desler, Gary, Human Resource Manajgement Tent Edition, New Jersey: Prentice Hall, 2003.

Devis, Keith Newton, Jhon W, Perilaku Dalam Organisasi, Jakarta: Erlangga, 1990.

Effendi, Agus,Revolusi Kecerdaan Abad 21, Bandung: Alfabeta, 2005.

Fatah, Nanang, Ekonomi dan Pembiayaan Pendidikan, bandung: PT Remaja Rosdakarya, 2000.

Flipo, Edwin, Manajemen Pendidikan Edisi Keenam, Jakarta: Erlangga, 1994.

Flipo, SE, Personal Management Sixt edition Singapura: Mc. Graww HillBoom Company, 1984.

Gobson, Organisasi, Perilaku Struktur dan Proses. Jakarta: Graha Banarupa Angsara, 2011.

Sinta Oktavianti1, M. Ihsan Dacholfany, Agus Sutanto, Pengaruh Kepemimpinan Kepala Sekolah dan Perilaku Kewarganegaraan Organisasi Terhadap Kinerja Guru Di SMP Se-Kecamatan Purbolinggo, Kabupaten Lampung Timur, Jurnal Lentera Pendidikan Pusat Penelitian LPPM UM METRO, Vol. 4, No. 2, Desember 2019

Sudarmo, Gito, Indrio dan Nyoman Sudiro, Perilaku Keorganisasian, Yogyakarta: BPFF, 1999.

Gomes, Faustino Cardoso, Manajemen Sumber Daya Manusia, Yogyakarta: Andi Offset, 1997.

Goleman, Daniel, Emotional Intelligenc, Alih Bahasa: Hermaya, Jakarta: Gramedia, 1997.

Hamzah B Uno, Orientasi baru dalam Psikologi Pembelajaran, Jakarta: PT BumiAksara, 2006.

Haesey Paul, Manajement Of Organization Behavior: Utilimizing Human Resourses, New Jersey: Prectice Hall, 1997

Heidjrachman and Suad Husnan, Management Personalia, Yogyakarrta: BPFF, 1993. 
Hein, Economic, Approach to Organization, New York: Prentice Hall, 1998.

Hesselbeil, Frances, Goldsmith Marshall, Beckhard, Richard, The Organization of the Future joey Biss Publishers, 2008. 